\title{
AiMT
}

Advances in Military Technology

Vol. 13, No. 1 (2018), pp. 71-86

ISSN 1802-2308, eISSN 2533-4123

DOI 10.3849/aimt.01218

\section{Determinants of Military Robotics Proliferation}

\author{
A. Olejníček* , J. Odehnal, V. Holcner and M. Krč \\ Faculty of Military Leadership, University of Defence in Brno, Czech Republic
}

The manuscript was received on 10 October 2017 and was accepted after revision for publication on 28 March 2018.

\begin{abstract}
:
The aim of the article is to define and quantify the determinants influencing the proliferation of robotic technology into the armament of the national armies and their use in combat operations. At the same time, the article focuses on identifying those countries which will deploy and use these advanced military technologies. Based on the literary research and its analysis, four categories of factors have been identified as the ones having influence on the military robotics proliferation. From the results of the classification model, it is clear that 78 analysed countries were classified on the basis of defined determinants into three groups with different assumptions of proliferation of military robotics. Based on the result of the cluster analysis, it is evident that military robotics proliferation was mainly affected by economic determinants in cluster 1, by security and political determinants in cluster 2 and by political and economic determinants in cluster 3.
\end{abstract}

\section{Keywords:}

military robotics, proliferation, security, political, military and economic determinants, cluster analysis, dendrogram

\section{List of Abbreviations}

$\begin{array}{ll}\text { EIUDI } & \text { Economist Intelligence Unit's Democracy Index } \\ \text { GCR } & \text { Global Competitiveness Report } \\ \text { GTI } & \text { Global Terrorism Index } \\ \text { GDP } & \text { Gross Domestic Product } \\ \text { ICRG } & \text { International Country Risk Guide } \\ \text { IEP } & \text { Institute for Economics and Peace } \\ \text { IFR } & \text { International Federation of Robotics } \\ \text { ILO } & \text { International Labor Organization } \\ \text { OECD } & \text { Organisation for Economic Co-operation and Development } \\ \text { UAVs } & \text { Unmanned Aerial Vehicles } \\ \text { UGVs } & \text { Unmanned Ground Vehicles }\end{array}$

\footnotetext{
* Corresponding author: Department of Economics, Faculty of Military Leadership, University of Defence in Brno, Kounicova 65, 66210 Brno, Czech Republic.

Phone: +4209734431 53,e-mail: ales.olejnicek@unob.cz
} 


\section{UMVs Unmanned Meritime Vehicles \\ USD United States Dollar}

\section{Introduction}

Nowadays, the use of robotics in the armament of the national armies has its irreplaceable position. The reason of this is that rapid development of this advanced technology brings obvious benefits. The most advanced development of this technology has been achieved in the area of aerial and ground-unmanned systems. Technologies and equipment designed to be used in water and underwater for a number of reasons have not yet reached such an extension as in the above-mentioned domains [1].

It is obvious that further proliferation of this technology into the armaments of national armies can be expected. Gates [2] compares the current level of maturity of robotic technology to that of computers in the 1970s, and assumes dynamic development of this technology. His prediction is also supported by expected development of the importance of robotic technology stated in the Global Trends study: Paradox of Progress [3].

The dynamics of the proliferation of robotic technology in the national states armies can be demonstrated by the speed of growth in its acquisition by individual states. As shown by some authors (see Tab. 1), in 2004, only 32 countries had robotic technology, but in 2015 the number of such countries increased to 90. As Tab. 1 shows, the prevalence of UAVs, it is caused mainly by development suitability of air domain in comparison with ground or water domain.

Tab. 1 Number of countries disposing of some form of robotic technology

\begin{tabular}{|c|c|c|c|}
\hline Year & $\begin{array}{l}\text { Number of } \\
\text { countries } \\
\text { listed in the } \\
\text { statistics }\end{array}$ & $\begin{array}{c}\text { Characteristics of the stated number of } \\
\text { countries }\end{array}$ & \begin{tabular}{|c|}
$\begin{array}{c}\text { Source of the } \\
\text { number of } \\
\text { listed coun- } \\
\text { tries }\end{array}$ \\
\end{tabular} \\
\hline 2004 & $32(41)^{1}$ & $\begin{array}{l}\text { Number of countries which buy and use } \\
\text { some type of UAVs }\end{array}$ & Maurer [4] \\
\hline 2011 & 76 & $\begin{array}{l}\text { Number of countries which buy and use } \\
\text { some type of UAVs }\end{array}$ & Melito [5] \\
\hline 2012 & 50 & $\begin{array}{l}\text { Number of countries which produce, buy } \\
\text { and use some type of the military robots }\end{array}$ & Singer [6] \\
\hline 2013 & 82 & $\begin{array}{l}\text { Number of countries owning one of the } \\
\text { types of UAVs }\end{array}$ & $\begin{array}{l}\text { Bergen, } \\
\text { Rothenberg [7] }\end{array}$ \\
\hline \multirow[b]{2}{*}{2014} & 50 & Number of countries developing UAVs & \multirow{2}{*}{$\begin{array}{l}\text { Davis, } \\
\text { McNerney [8] }\end{array}$} \\
\hline & 70 & $\begin{array}{l}\text { Number of countries which buy and use } \\
\text { UAVs }\end{array}$ & \\
\hline \multirow[b]{2}{*}{2015} & 90 & Number of countries disposing of UAVs & \multirow[b]{2}{*}{ Sayler [9] } \\
\hline & 30 & $\begin{array}{l}\text { Number of countries disposing or developing } \\
\text { lethal UAVs }\end{array}$ & \\
\hline
\end{tabular}

As indicated by the development itself, it is clear that in a relatively short period of time, there has been a significant increase in the number of countries that develop and use robotic technology in their armed forces, or develop and produce them within

\footnotetext{
${ }^{1}$ The higher number " 41 " is stated in the later 2012 report. The 2004 report states "at least 32 countries".
} 
its defence industry. The proliferation of military robotics needs to be understood in the context of its development and the degree of real operational use. The number of countries that own robotic technology is high. It is a sign of acceptance of the usability and usefulness of this technology designed for military purposes.

However, it is necessary to draw attention to the fact that this quantitative increase is not equally accompanied by development in qualitative terms. Although many countries already use this technology in military terms, these are usually only pieces or dozens of this equipment. A significantly smaller number of countries have at their disposal more advanced forms of these technologies, as well as the ability to develop and produce such technologies $[10,11]$.

It is quite logical to ask what the cause of proliferation of this robotic technology into national armies is and what motivates the armies to invest in the purchase or development of this kind of robotic technology.

The proliferation of military robotics will be influenced by a number of determinants. At the same time, it is obvious that the massive development of the use of robotic systems in national armies in the last decade is a logical outcome of general technological trends which can be seen in the process automation, robotisation and the development of artificial intelligence. This has been apparent not only in the life of society and its members, but also in the development of armies since the beginning of the industrial revolution [12].

\section{Research and Methodology}

Professional literature dealing with the issue of proliferation of military robotics can be divided into several groups. Either the authors discuss the proliferation of robotics in general without a specific focus on one of its groups $[8,13,14]$, or they focus on a particular domain of robotic technology, usually the UAVs $[15,16]$. Another group of authors focuses on defining and analysing particular determinants [17, 18]. A part of them usually concentrate on one or more possible determinants within the wider context of military robotics proliferation [19], other authors include in their analysis also prognosis trying to state which countries are most likely to begin to develop or purchase this technology - however, without presenting an empirical concretisation of the methodology of this prognosis. The last group, the least numerous, defines the prognosis of further proliferation of military robotics with the empirical concretization of the prognostic methodology [20].

The scope and focus of the study of the proliferation determinants of military robotics can be plotted using two-axis quadrants. The vertical axis expresses the degree of complexity of investigating the military robotics proliferation; the horizontal axis expresses the measure of empirical demonstrability of further proliferation of military robotics (see Fig. 1).

The level of complexity of the study of military robotics is determined by the extent of the discussion of the individual operating domains of robotic technology (i.e. whether the publication deals with all types of robotic systems or focuses on one selected area) and the number of determinants of the military robotics proliferation. The level of empirical provability of the military robotics proliferation is determined by choosing those methods or tools which support the credibility and objectivity of the proliferation of this technology (i.e. whether an expert judgment or appropriate mathematical apparatus is used). 


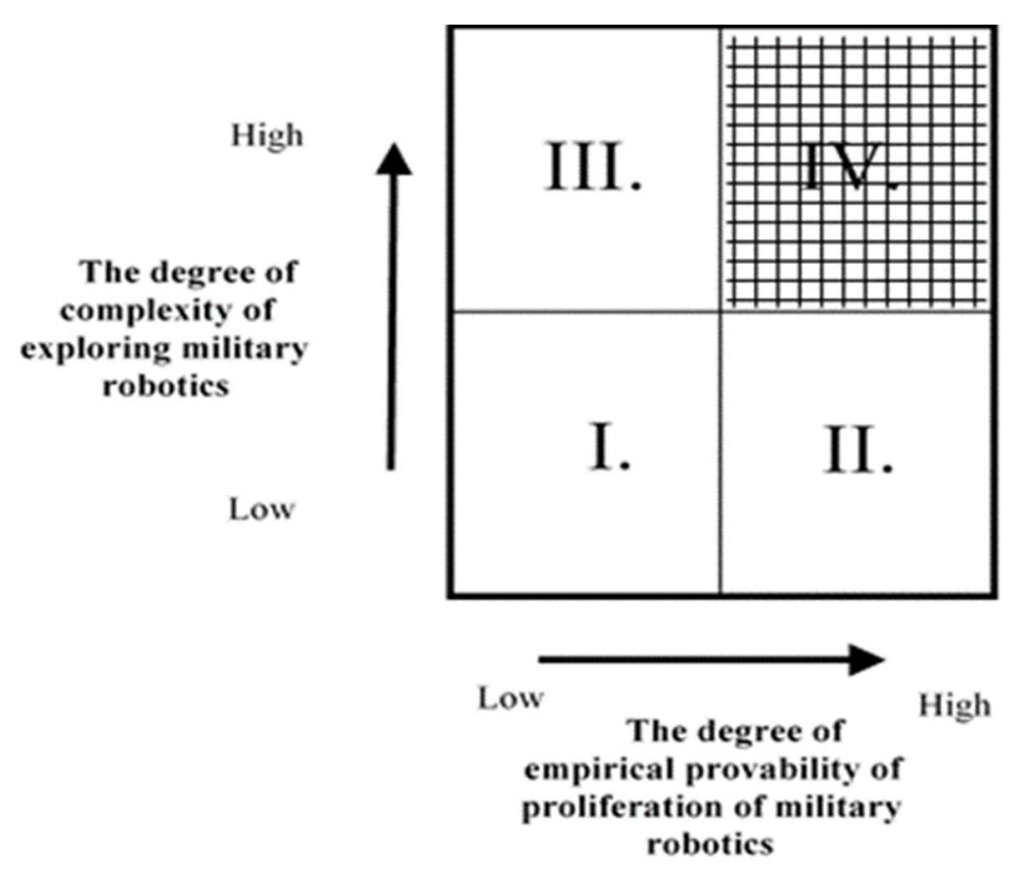

Fig. 1 Classification matrices of the scope and focus of the study of the proliferation of military robotics

Using the classification described above, most of the available publications can be classified in quadrants either I. (11 publications) or III. (4 publications). The residual number of publications would then be in quadrant II. (2 publications). However, it is not possible to include any work published so far into quadrant IV.

Literary research has found that the determinants influencing the military robotics proliferation can be classified according to their field of activity affecting proliferation of this technology into armaments of national armies. According to this criterion, determinants can be defined as follows:

- security,

- political,

- military and

- economic.

Security determinants can be expected to be factors directly or indirectly related to the security of the country. In case of these determinants, countries are expected to be more predisposed to the introduction of robotic technology if they have to face real security threat. Horowitz, Kreps and Fuhrmann [10] draw attention to the fact that sharing borders with conflicting neighbours, together with the threat of a terrorist attack and some form of participation in current conflicts, is a powerful motivator for considering the implementation of robotic technology. The ability to monitor the movement of risk persons or the movement of persons in the area of interest may help reduce the level of security risk. Hall, Coyne and Goodell $[18,19]$ are also coming to similar conclusions.

Political determinants are related to aspects that affect the political decision-making process within the country, as well as the involvement in international political structures. Horowitz, Kreps and Fuhrmann [10], Caverley [21] or Gartzke [22] bring 
a very interesting insight - these authors independently came to the conclusion that both highly developed democracies and authoritative regimes have the incentives to acquire robotic technology, of course with different motivations. With the use of robotic technology in the future, the need for the current number of soldiers on the battlefield can decrease. This can lead to the reduction of combat casualties, which is very desirable from a political point of view, as stated by Hall and Coyne [18], Schörnig [23] or Horowitz and Fuhrmann [20].

Military determinants can be considered as factors that lead to an increased interest in the introduction of robotic technology by the military. Basically, we should talk about the facts which approve robotics for military use. This means that the technology - military robotics - is so advanced that it can deliver the expected benefits with an appropriate degree of reliability. Technical aspects of the development of robotics in military environment are partly covered by military determinants. Horowitz, Fuhrmann and Kreps [10] point out to the fact that the acceptance and purchase of military robotics are more expected in less sophisticated systems than in more sophisticated systems; it is then not only the number, but also the level of technical development and usability of the technology are decisive for their acquisition by national states. Cole [16] suggests a direct link between the number of robotic devices used and their subsequent acquisition. Hall and Coyne conclude on the basis of the historical and logical analysis that the progress of this technology has been proportionally influenced by the maturity of available technologies such as sensors, communication technologies and articulated interest coming from the army. Their conclusions show that the degree of robotisation of the army is a very important factor. Goodell emphasizes the impact of combat casualties the higher the combat losses, the higher the willingness to invest in purchasing the robotic systems can be. Hall and Coyne [18] draw attention to the emerging personnel gap of armies as another determinant of the proliferation of military robotics (the impact of population development and population health).

Economic determinants are related to economic performance, the objective economic and financial profitability of manufacturing, purchasing, and the use of robotic technology for military purposes. According to Goodel [19], the introduction of robotic technology into army conditions is generally influenced by the overall situation of the state's economy, which also affects the state of public budgets. Cole [16], Hall and Coyne [18], Lynn and McNerney [8] underline the fact that stabilized public budgets create, among other things, a good situation for increasing military investment. Barkan [24] draws attention to the political overtones concerning military spending decisions. The Tofflers [17] perceive the cost of labour and the value of human life as one of the most important factors influencing the introduction of robotic technology. The more expensive human labour, the stronger the incentives to use the robots are expected, and at the same time the substitution of labour by capital will contribute to the protection of human life. Hall and Coyne [18], Lynn and McNerney [8], Schörnig [23], also Horowitz and Fuhrmann [20] believe that the size of the military robotics market and its development are significant factors in the military robotics proliferation. Hall and Coyne [18] further demonstrate the tendencies of the most important market representatives to influence the size of military investment expenditure to their advantage. A list of the most important determinants is given in Tab. 2. 
Tab. 2 Overview of determinants defined in selected publications as determinants of the proliferation of military robotics

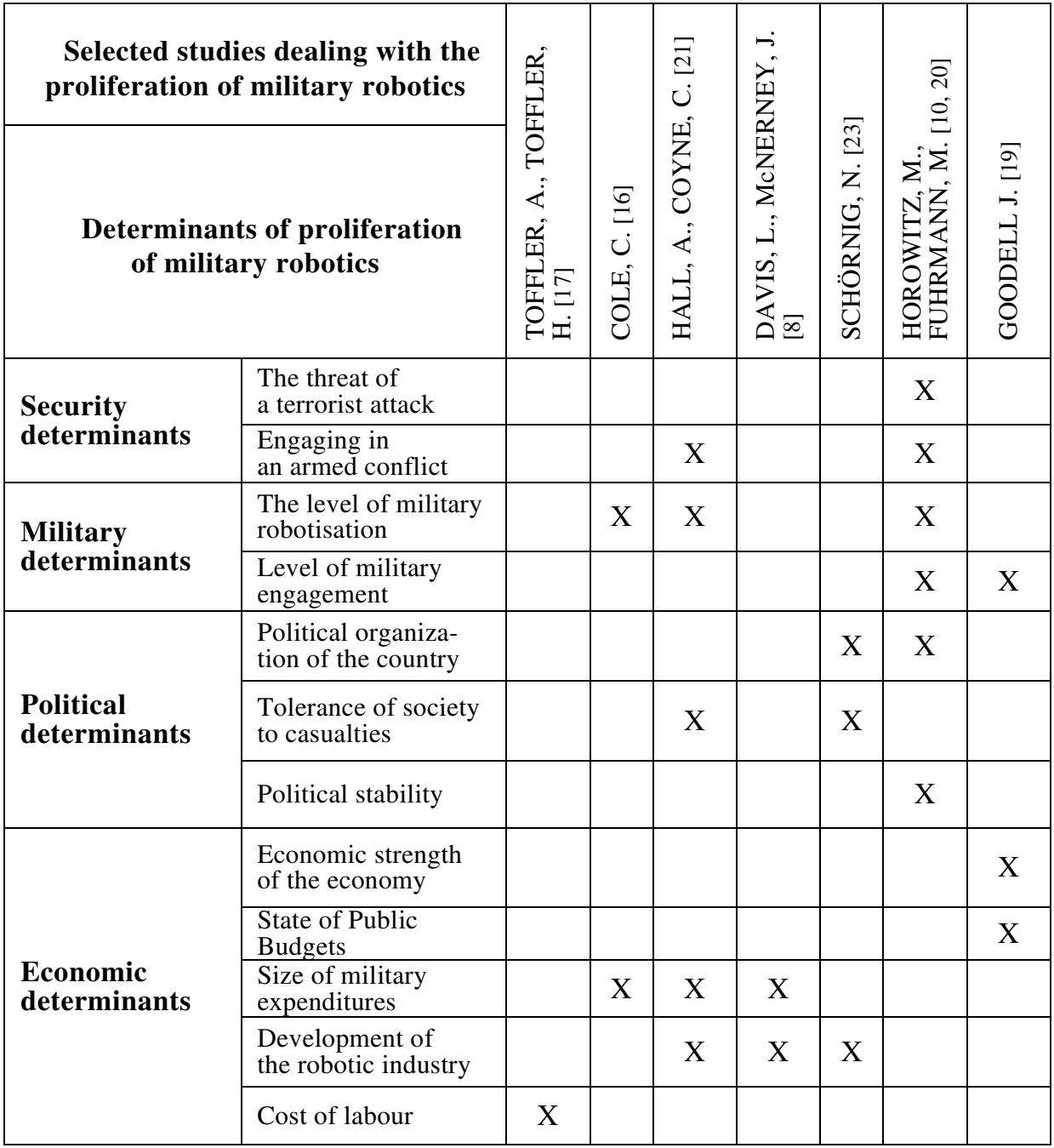

The determinants shown in Tab. 2 represent a framework overview of indicators to derive and quantify the data sets usable to perform a multidimensional analysis of the variables predicted for the proliferation of military robotics.

As another necessary step for performing multidimensional analysis of determinants of proliferation of military robotics, it is necessary to determine and quantify the variables for the above mentioned types of determinants. For this purpose, and to ensure the relevance of the results of the analysis, the data were drawn from globally recognized databases, in particular from the SIPRI, ICRG, EIUDI, GTI, GPI, IEP, ILO, GCR, IFR, OECD databases characterizing the security, military, political and economic determinants of proliferation military robotics. A summary overview of each variable is provided in Tab. 3. 
By creating a data set to present the outlook for possible proliferation of military robotics, several goals have been pursued:

- to present a prediction that would not only focus on a particular segment of military robotics, but it would be applicable to all domains (air, ground, water), i.e. to achieve the highest level of complexity of military robotics;

- to present a prediction that would take into account the wider field of determinants of the development of military robotics, i.e. to achieve the highest degree of empirical provability of proliferation of military robotics;

- to submit a study that could fill the place in quadrant IV of the classification matrices examining the proliferation of military robotics (see Fig. 1).

The following restrictive conditions were found when creating a data file for the prediction of proliferation of military robotics:

- availability and completeness of data for the final number of countries (limited possibility of creating a comprehensive data set for as many countries as possible);

- sole quality and accuracy of data used in multidimensional analysis of the determinants of proliferation of military robotics.

In order to minimize the effects of the above limitations, the data were obtained mainly from the verified world-wide databases (see Tab. 3).

\section{Multidimensional Analysis of Determinants of Military Robotics Proliferation}

The general objective of multidimensional analysis of the determinants of military robotics proliferation is to create a classification of countries with similar values of quantified determinants.

\subsection{Analyzed Data Set of Variable Determinants of Military Robotics Proliferation}

The analyzed data set (the data were standardized before the analysis) describes the determinants of military robotics proliferation of selected 78 countries. Each country was characterized by variables of individual types of determinants (see Tab. 3 or Tab. 4). Based on literary research, nineteen quantifiable variables were defined. In the case of security determinants, there were three variables, the military determinants were represented by two variables, the political determinants by three variables and the economic determinants included eleven variables. All analyzed variables were dated to 2015 .

\subsection{Cluster Analysis of Determinants of Military Robotics Proliferation}

The result of cluster analysis (Euclidean distances, Ward method, linkage distance 26) is a classification of countries based on 19 variables quantifying the above-mentioned determinants of proliferation of military robotics (see Fig. 2). The created classification is represented by a so-called dendrogram, and the clusters of countries are compared based on the average values of the analyzed variables in order to find the same values of the determinants as the basic assumption of the further development of military robotics.

The dendrogram consists of a tree diagram and two additional perpendicular axes where individual clustered objects appear along one axis and the linkage distance values (the distances between clustered objects) along the other axis [25-28]. 
Tab. 3 Overview of variables for quantification of the determinants of the proliferation of military robotics

\begin{tabular}{|c|c|c|c|c|}
\hline \multirow{2}{*}{\multicolumn{2}{|c|}{$\begin{array}{l}\text { Proliferation Determinants of } \\
\text { military robotics }\end{array}$}} & \multicolumn{3}{|c|}{ Variables for quantification of determinants } \\
\hline & & Variable & Unit & $\begin{array}{c}\text { Source of } \\
\text { the relevant }\end{array}$ \\
\hline \multirow{3}{*}{ 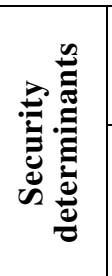 } & $\begin{array}{l}\text { The threat of a terrorist } \\
\text { attack }\end{array}$ & Global terrorist index & $\begin{array}{l}\text { Scale } \\
(0,10)\end{array}$ & $\begin{array}{l}\text { Institute for } \\
\text { Economics } \\
\text { and Peace }\end{array}$ \\
\hline & \multirow{2}{*}{$\begin{array}{l}\text { Engaging in an armed } \\
\text { conflict }\end{array}$} & Risk of a war & $\begin{array}{l}\text { Scale } \\
(0,7)\end{array}$ & $\begin{array}{l}\text { The Global } \\
\text { Economy }\end{array}$ \\
\hline & & $\begin{array}{l}\text { Risk of internal and } \\
\text { external conflict }\end{array}$ & $\begin{array}{l}\text { Scale } \\
(0,4)\end{array}$ & $\begin{array}{l}\text { Global } \\
\text { Peace Index }\end{array}$ \\
\hline \multirow{2}{*}{ 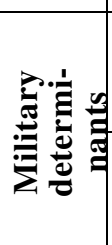 } & $\begin{array}{l}\text { The level of military } \\
\text { robotisation }\end{array}$ & $\begin{array}{l}\text { Proportion of robotic } \\
\text { technology in } \\
\text { armaments }\end{array}$ & $\%$ & $\begin{array}{l}\text { IISS/ } \\
\text { Military } \\
\text { Balance/ }\end{array}$ \\
\hline & $\begin{array}{l}\text { Level of military } \\
\text { engagement }\end{array}$ & $\begin{array}{l}\text { Number of soldiers } \\
\text { involved in military } \\
\text { operations }\end{array}$ & $\begin{array}{l}\text { Number of } \\
\text { people }\end{array}$ & $\begin{array}{l}\text { IISS/ } \\
\text { Military } \\
\text { Balance/ }\end{array}$ \\
\hline \multirow{3}{*}{ 氖芯 } & $\begin{array}{l}\text { Tolerance of society to } \\
\text { casualties }\end{array}$ & $\begin{array}{l}\text { Number of killed } \\
\text { soldiers }\end{array}$ & $\begin{array}{l}\text { Number of } \\
\text { people }\end{array}$ & $\begin{array}{l}\text { Prior Battle } \\
\text { Deaths Data }\end{array}$ \\
\hline & $\begin{array}{l}\text { Political organization } \\
\text { of the country }\end{array}$ & Index of Democracy & $\begin{array}{l}\text { Scale } \\
(0,10)\end{array}$ & $\begin{array}{l}\text { Economist } \\
\text { Intelligence } \\
\text { Unit }\end{array}$ \\
\hline & Political stability & $\begin{array}{l}\text { Index of risk to } \\
\text { political stability }\end{array}$ & $\begin{array}{c}\text { Scale } \\
(-2.5,2.5)\end{array}$ & $\begin{array}{l}\text { The Global } \\
\text { Economy }\end{array}$ \\
\hline \multirow{11}{*}{ 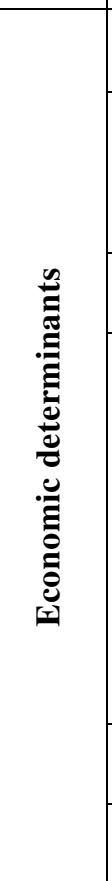 } & \multirow{2}{*}{$\begin{array}{l}\text { Economic strength } \\
\text { of the economy }\end{array}$} & GDP/population & USD & World Bank \\
\hline & & Economic growth & $\%$ GDP & World Bank \\
\hline & \multirow{2}{*}{ State of Public Budgets } & Deficit/Surplus & $\%$ GDP & $\begin{array}{l}\text { Global } \\
\text { Finance }\end{array}$ \\
\hline & & Public debt & $\%$ GDP & $\begin{array}{l}\text { Global } \\
\text { Finance }\end{array}$ \\
\hline & $\begin{array}{l}\text { Size of military } \\
\text { expenditures }\end{array}$ & $\begin{array}{l}\text { Size of military } \\
\text { expenditures }\end{array}$ & $\%$ GDP & SIPRI \\
\hline & \multirow{4}{*}{ Competitiveness } & Modern technologies & $\begin{array}{l}\text { Scale } \\
(0,7)\end{array}$ & GCR \\
\hline & & $\begin{array}{l}\text { Absorption of tech- } \\
\text { nologies by the } \\
\text { private sector }\end{array}$ & $\begin{array}{l}\text { Scale } \\
(0,7)\end{array}$ & GCR \\
\hline & & $\begin{array}{l}\text { Government pur- } \\
\text { chases of advanced } \\
\text { technologies }\end{array}$ & $\begin{array}{l}\text { Scale } \\
(0,7)\end{array}$ & GCR \\
\hline & & $\begin{array}{l}\text { Companies' } \\
\text { innovations }\end{array}$ & $\begin{array}{l}\text { Scale } \\
(0,7)\end{array}$ & GCR \\
\hline & Cost of labour & Hourly labour costs & USD & $\begin{array}{l}\text { ILC, } \\
\text { Eurostat }\end{array}$ \\
\hline & $\begin{array}{l}\text { Development of the } \\
\text { robotic industry }\end{array}$ & Density of robots & $\begin{array}{l}\text { Robot/ } \\
\text { worker }\end{array}$ & IFR \\
\hline
\end{tabular}




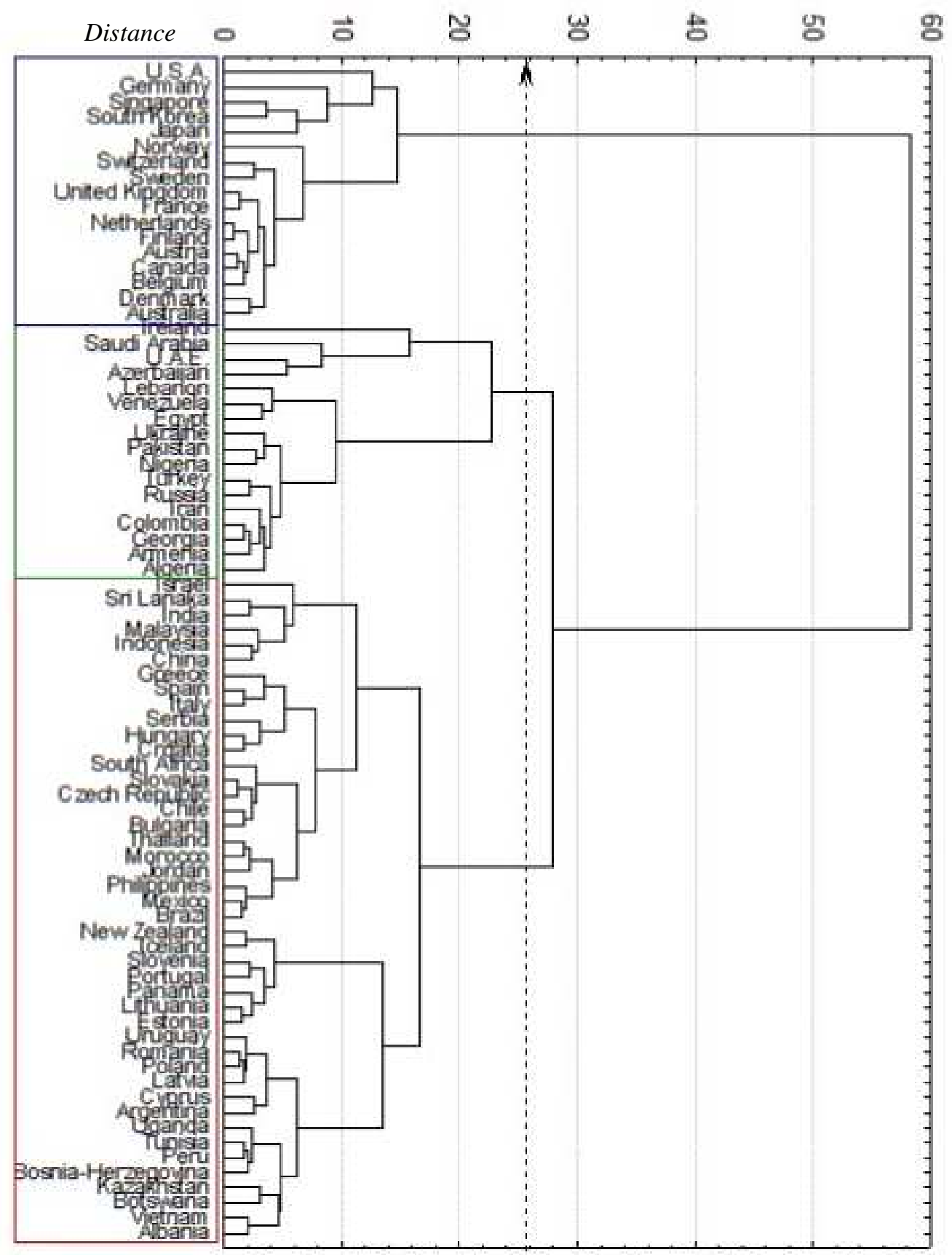

Fig. 2 Results of cluster analysis of military robotics proliferation determinants (2015)

The analysed set (the 2015 data) shown in Fig. 2 represents the classification of 78 countries divided into three clusters. The first cluster is made up of 17 countries, the second cluster is made up of 17 countries and the third cluster is made up of 44 countries. 
The first cluster is made up of countries that can be included into highly developed countries with a developed and stable democratic system. Almost all of them use robotic technology in national armies and, in addition, most of them can be considered as the producer of this technology. Some of them are even able to develop and produce the most sophisticated robotic systems. At the same time, these are countries with a high number of soldiers in foreign missions and the highest density of military robotics.

The second cluster is made up of two thirds by developing countries; the rest can be described as transitive countries. A hybrid or authoritative political systems prevail. All countries have robotic technology in their national armies and one third of them are developing a more sophisticated type of robotic technology. The number of soldiers in foreign missions is not insignificant; however, they have the lowest density of military robotics out of the analyzed countries. A significant amount of wartime casualties represents a common feature for the countries of this cluster.

The third cluster is made up of the largest group of countries; three quarters of them are countries with a developed democratic system; the remaining quarter is partly composed of authoritative countries and countries with a hybrid system. From an economic point of view, this cluster is made up of a half of developed countries and a half of developing countries. More than $50 \%$ of the countries have some of the available types of robotic technology. Only 6 countries are producers of one of the current military robotic systems. The number of soldiers in foreign missions is the lowest among the three monitored groups of countries; the density of military robotics is comparable to that of the second cluster countries.

The analysis suggests that in demarcated clusters of countries, individual determinants of military robotics proliferation have different weight. Table 4 shows which variables of determinants in individual clusters of countries achieve the highest values when compared with other clusters and thus have an impact on the robotic technology proliferation.

As for cluster 1, especially military and economic determinants can be seen as the most important ones (high numbers of soldiers in foreign countries, high density of military robotics, high GDP per capita, high labour costs and a high level of competitiveness). Nevertheless, political determinants play a significant role, too. For cluster 2 , the situation is somewhat different, since not only security and political determinants (high risk of war, internal or external conflict, high terrorism risk, high numbers of soldiers killed, and high index of political instability), but also two economic variables (GDP growth rate, the size of military spending) achieve the highest values. In cluster 3 , the countries have a more balanced influence of especially political, economic and military determinants, but with significantly less intensity compared to other clusters of countries (variables such as robotics development, availability of modern technologies, robotics density or the number of killed soldiers is more intense than in cluster 2 countries).

The above stated characteristic shows that the countries in individual clusters approach the proliferation of military robotics under the influence of different variables of individual determinants (see Tab. 4 bellow).

For variables $1-6,9,10,13-19$, the higher the value, the stronger the effect on the proliferation of robotics can be expected; for variables 7 and 8, values in the upper or lower value range can be seen as strongly influencing; for variable 11, propitious values are zero and positively growing, for negative positively decreasing to zero. For variable 12 , lower value can be perceived as positive. 
Tab. 4 Average values of determinants at defined clusters of countries (2015)

\begin{tabular}{|c|c|c|c|c|}
\hline \multicolumn{2}{|c|}{ Characteristics of determinants } & \multicolumn{3}{|c|}{$\varnothing$ values of variables } \\
\hline Name & Variable & $\begin{array}{c}\text { Cluster } \\
\text { no. } 1\end{array}$ & $\begin{array}{c}\text { Cluster } \\
\text { no. } 2\end{array}$ & $\begin{array}{c}\text { Cluster } \\
\text { no. } 3\end{array}$ \\
\hline \multirow{3}{*}{ Security } & 1. Risk of war (unit) & 1.19 & 4.47 & 2.25 \\
\hline & $\begin{array}{l}\text { 2. Risk of internal and } \\
\text { external conflict GPI }\end{array}$ & 1.57 & 2.59 & 1.87 \\
\hline & $\begin{array}{l}\text { 3. Risk of terrorism GTI } \\
\text { (unit) }\end{array}$ & 2.55 & 5.27 & 2.19 \\
\hline \multirow{2}{*}{ Military } & $\begin{array}{l}\text { 4. Number of soldiers in } \\
\text { foreign missions }\end{array}$ & 16789 & 5745 & 1241 \\
\hline & $\begin{array}{l}\text { 5. Density of military } \\
\text { robotics }(\%)\end{array}$ & 0.08607 & 0.03283 & 0.03482 \\
\hline \multirow{3}{*}{ Political } & $\begin{array}{l}\text { 6. Intolerance to war victims } \\
\text { (number of people killed) }\end{array}$ & 461 & 12165 & 8723 \\
\hline & $\begin{array}{l}\text { 7. Nature of country's } \\
\text { political organization }\end{array}$ & 8.53 & 4.39 & 6.69 \\
\hline & 8. Political stability & 0.85 & -0.95 & 0.09 \\
\hline \multirow{11}{*}{ Economic } & $\begin{array}{l}\text { 9. Share of Gross Domestic } \\
\text { Product per Capita (USD) }\end{array}$ & 48017 & 10829 & 14762 \\
\hline & $\begin{array}{l}\text { 10. Economic growth } \\
(\% \text { GDP })\end{array}$ & 1.76 & 5.07 & 3.79 \\
\hline & $\begin{array}{l}\text { 11. Deficit/Surplus } \\
(\% \text { GDP })\end{array}$ & -1.01 & -3.35 & -2.72 \\
\hline & 12. Debt (\% GDP) & 79 & 44 & 58 \\
\hline & $\begin{array}{l}\text { 13. Size of military } \\
\text { expenditures (\% GDP) }\end{array}$ & 1.64 & 3.84 & 1.61 \\
\hline & $\begin{array}{l}\text { 14. Availability of modern } \\
\text { technologies }\end{array}$ & 6.22 & 4.51 & 4.99 \\
\hline & $\begin{array}{l}\text { 15. Level of technology } \\
\text { absorption by companies }\end{array}$ & 5.68 & 4.39 & 4.68 \\
\hline & $\begin{array}{l}\text { 16. Government purchases of } \\
\text { advanced technologies }\end{array}$ & 3.88 & 3.36 & 3.28 \\
\hline & 17. Company innovations & 5.42 & 4.12 & 4.28 \\
\hline & $\begin{array}{l}\text { 18. Cost of labour } \\
\text { (USD/hour) }\end{array}$ & 37.44 & 6.08 & 9.05 \\
\hline & $\begin{array}{l}\text { 19. Development of robotics } \\
\text { (robot/10 } 000 \text { workers) }\end{array}$ & 192 & 31 & 41 \\
\hline
\end{tabular}




\section{Results and Discussion}

Based on the created clusters of countries and acquired values of individual variable determinants, it is possible to identify countries that have a dominant position in the use and further development of military robotics, as well as states with significant growth potential. The determined countries are those which acquire the highest values at each variable in comparison with the average values of the variables in the clusters of countries. At the same time, the next criterion for inclusion in both groups is the rate of achievement of the above-average values of the variables of the observed determinants and the current state of development of military robotics. An overview of countries where both quantitative and qualitative development of military robotics can be expected is provided by Tab. 5 .

Tab. 5 Proliferation of military robotics based on cluster analysis of its determinants

\begin{tabular}{|c|c|c|}
\hline \multirow{2}{*}{$\begin{array}{l}\text { Clusters of } \\
\text { countries }\end{array}$} & \multicolumn{2}{|c|}{$\begin{array}{l}\text { Countries which determine and participate in prolifera- } \\
\text { tion of robotics }\end{array}$} \\
\hline & Dominating countries & $\begin{array}{l}\text { Countries with growth poten- } \\
\text { tial }\end{array}$ \\
\hline $\begin{array}{l}\text { Cluster of } \\
\text { countries No. } 1\end{array}$ & $\begin{array}{l}\text { Australia, France, Germany, } \\
\text { United States of America, } \\
\text { United Kingdom }\end{array}$ & $\begin{array}{l}\text { Belgium, Denmark, Finland, } \\
\text { The Netherlands, Norway, South } \\
\text { Korea, Singapore, Sweden, } \\
\text { Switzerland }\end{array}$ \\
\hline $\begin{array}{l}\text { Cluster of } \\
\text { countries No. } 2\end{array}$ & $\begin{array}{l}\text { United Arab Emirates, Saudi } \\
\text { Arabia, Russia, Turkey, Pa- } \\
\text { kistan, Ukraine, }\end{array}$ & $\begin{array}{l}\text { Lebanon, Azerbaijan, Armenia, } \\
\text { Nigeria, Iran, Algeria, Colom- } \\
\text { bia, Egypt, Georgia, Venezuela }\end{array}$ \\
\hline $\begin{array}{l}\text { Cluster of } \\
\text { countries No. } 3\end{array}$ & $\begin{array}{l}\text { China, Israel, Czech Repub- } \\
\text { lic, India, Jordan, Indonesia, } \\
\text { Italy, Sri Lanka, South Af- } \\
\text { rica, Slovakia, Thailand }\end{array}$ & $\begin{array}{l}\text { Burundi, Luxembourg, Portugal, } \\
\text { Estonia, Ethiopia, Ireland, New } \\
\text { Zealand, Uganda }\end{array}$ \\
\hline
\end{tabular}

For the states labeled as dominating, there is a strong assumption that they will experience the qualitative development of robotic technology that will be reflected in the production and development of advanced systems or systems with the ability to perform lethal combat operations. For countries with growth potential, quantitative development is expected, manifested in the early years of robotic technology or other investment in the purchase or development of robotic technology.

For comparison with other prognosis of the military robotics proliferation, Tab. 6 is shown. This table contains predictions from Farley [29], Horowitz and Fuhrmann [20].

Comparison of the presented expectations of proliferation of military robotics shows both difference and accord. However, the cluster-based prognosis takes into account considerably more variables in the analyzed kinds of determinants. Thus, it creates a prerequisite for a more general validity affecting all domains in which military robotics can be used.

\section{Conclusion}

The interest in the explanation and prognosis of the robotic technology proliferation in the environment of the national armies has focused primarily on the area of UAVs, without 
detailed classification and specification of the individual determinants. The submitted contribution shows that the proliferation of military robotics is influenced by security, military, political and economic determinants. The definition of variables for the quantification of the influence of determinants and the chosen method of cluster analysis were guided by the effort of applicability in all robotic domains (UAVs, UGVs, UMVs) and at the same time by trying to achieve the highest possible empirical provability of the prognosis. From the point of view of classification of literary sources, it is possible to include this contribution among the first representatives of quadrant IV. of Fig. 1.

In conclusion, it can be said that the robotic technology proliferation will be visible in those countries that will achieve the above-average values of the individual variables of the determinants mentioned above. Gradually, there may be a transition between the clusters of countries and between the dominant states and the countries with growth potential.

Tab. 6 Comparison of predictions of possible military robotics proliferation (selected authors)

\begin{tabular}{|l|c|c|}
\hline \multirow{2}{*}{$\begin{array}{c}\text { Authors predicting } \\
\text { possible military ro- } \\
\text { botics proliferation }\end{array}$} & \multicolumn{2}{|c|}{$\begin{array}{c}\text { States that determine and participate in robotics pro- } \\
\text { liferation }\end{array}$} \\
\cline { 2 - 3 } & $\begin{array}{c}\text { Dominating } \\
\text { countries }\end{array}$ & \multicolumn{1}{c|}{ Countries with growth potential } \\
\hline Farley [29] & $\begin{array}{c}\text { United States, China, } \\
\text { Israel, Iran, Russia }\end{array}$ & India, Brazil, France \\
\hline $\begin{array}{l}\text { Horowitz, Fuhrmann } \\
{[10,20]-\text { advanced }} \\
\text { UAVs }\end{array}$ & - & $\begin{array}{l}\text { Japan, Spain, Canada, Kazakhstan, } \\
\text { Saudi Arabia, Ireland, Bahrain, } \\
\text { Colombia, Qatar, Greece }\end{array}$ \\
\hline $\begin{array}{l}\text { Horowitz, Fuhrmann } \\
{[10,20]-\text { combat }} \\
\text { UAVs }\end{array}$ & - & $\begin{array}{l}\text { Ireland, Bahrain, Iraq, Canada, } \\
\text { Indonesia, Colombia, Cyprus, } \\
\text { Philippines, Chile, Thailand }\end{array}$ \\
\hline
\end{tabular}

\section{Acknowledgement}

The work presented in this paper has been supported by the Ministry of Defence of the Czech Republic (Advanced Automatized Comand and Control System II).

\section{References}

[1] MURPHY A. Military: Robotics Outlook 2025 [on line]. 2017. Loup Ventures. [cited 2017-03-04]. Available from: <http://loupventures.com/military-roboticsoutlook-2025/>.

[2] GATES, B. A Robot in Every Home: The leader of the PC revolution predicts that the next hot field will be robotics. 2007. Scientific American, 2007, vol. 296, no. 1, p. 58-65. ISSN 0036-8733.

[3] Global Trends: Paradox of Progress [on line]. Washington: Office of the Director of National Intelligence. 2017. [cited 2017-03-05]. Available from: $<$ https://www.dni.gov/index.php/global-trends-home>. 
[4] MAURER, D. Improvements Needed to Better Control Technology Exports for Cruise Missiles and Unmanned Aerial Vehicles (GAO-04-175 [on line]. Washington: U.S. General Accounting Office, 2004, 63 p. [cited 2017-05-07]. Available from: <http://www.gao.gov/assets/250/241243.pdf>.

[5] MELITO, T. Agencies Could Improve Information Sharing and End-Use Monitoring on Unmanned Aerial Vehicle Exports (GAO-12-536) [on line]. Washington: U.S. General Accounting Office, 2012, 58 p. [cited 2016-08-19]. Available from: http://www.gao.gov/assets/600/593131.pdf>.

[6] SINGER, P. W. The Robotics Revolution [on line]. Washington: Brookings, 2012. [cited 2016-08-18]. Available from: <https://www.brookings.edu/opinions/the-robotics-revolution/>.

[7] BERGER, P.L. and ROTHENBERG, D. Drone wars: transforming conflict, law, and policy. In BERGER, P.L. and ROWLAND, J. (eds). World of Drones: The Global Proliferation of Drone Technology. New York: Cambridge University Press, 2015, p. 300-341. ISBN 978-1-107-02556-1.

[8] DAVIS, L.E., McNERNEY, M.J., CHOW, J., HAMILTON, T., HARTING, S. and BYMAN, D. Armed and dangerous?: UAVs and U.S.security. Santa Monika: RAND Corporation, 2014. 34 p. ISBN 978-0-8330-85887.

[9] SAYLER, K. A World of Proliferated Drones: A Technology Primer [online]. Washington: Center for a New America Security, 2015, [cited 2017-02-18]. Available from: <https://www.files.ethz.ch/isn/191911/CNAS\%20World\%20of\%20 Drones_052115.pdf $>$.

[10] HOROWITZ, M.C., KREPS, S.E. and FUHRMANN, M. 2016. The Consequences of Drone Proliferation: Separating Fact from Fiction. International Security, vol. 42, no. 2, p. 7-42. DOI 10.1162/ISEC_a_00257.

[11] BERGEN, P. and STERMAN D. Who Has What: Countries Developing Armed Drones [on line]. In Depth World of Drones: World of Drones. Washington D.C.: New America, 2016. [cited 2017-04-22]. Available from: <https://www.newamerica.org/in-depth/world-of-drones/4-who-has-what-countries-developing-armeddrones/>.

[12] SUMMEY, D.C., RODRIGUEZ, R.R. and DEMARTINO, D.P. Shaping the Future of Naval Warfare with Unmanned Systems [on line]. In: Performing Organization Report. Panama City, Florida: Dahlgren Division Naval Surface Warfare Center, 2001. [cited 2017-02-02]. Available from: <https://www.academia.edu/ 2681124/Shaping_the_Future_of_Naval_Warfare_Witth_Unmanned_Systems $>$.

[13] SINGER, P.W. Wired for war: The Robotics Revolution and Conflict in the Twenty-first Century. New York: Penguin Press, 2009. 499 p. ISBN 978-1-59420198-1.

[14] SZABOLCSI, R. The Birth of the Term Robot. Advances in Military Technology, 2014, vol. 9, no. 1, p. 117-128. ISSN 1802-2308.

[15] SINGER, P.W. Die Zukunft ist schon da: Die Debatte über Drohnen muss von Realitäten ausgehen [on line]. IP-Die Zeitschrift. Berlin: Deutsche Gesellschaft für Auswärtige Politik, 2013. [cited 2017-05-22]. Available from: <https://zeitschriftip.dgap.org/de/ip-die-zeitschrift/archiv/jahrgang-2013/mai-juni/die-zukunft-istschon-da>. 
[16] COLE, C. Mapping Drone Proliferation: Big Business vs. the MTCR [on line]. Drone Wars UK. Oxford: Peace House, 2012. [cited 2017-03-04]. Available from: $<$ https://dronewars.net/2012/09/18/mapping-drone-proliferation-big-business-vsthe-mtcr/\#GAOlist $>$.

[17] TOFFLER, A. and TOFFLER, H. War and Antiwar. New York: Warner Books, 1993, 245 p. ISBN 04-466-0259-0.

[18] HALL, A.R. and COYNE, C.J. The Political Economy of Drones [on line]. Defence and Peace Economics. 2014, vol. 25, no. 5, p. 445-460. ISSN 1476-8267. DOI 10.1080/10242694.2013.833369.

[19] GOODELL, J. Inside the Artificial Intelligence Revolution: A Special Report, Pt. 2: Self-Driving Cars, War Outsourced to Robots, Surgery by Autonomous Machines - This is only the Beginning [on line]. Rolling Stone. New York: Wenner Media, 2016. [cited 2017-03-04]. Available from: <http://www.rollingstone.com/culture/features/inside-the-artificial-intelligence-revolution-aspecial-report-pt-2-20160309>.

[20] HOROWITZ, M.C. and FUHRMANN, M. Droning On: Explaining the Proliferation of Unmanned Aerial Vehicles [on line]. GSPIA, 2014. [cited 2017-07-29]. Available from: <http://www.gspia.pitt.edu/Portals/26/PDF/HF\%20Drone\%20 Proliferation\%209\%2012\%2014\%20-\%20Pitt.pdf>.

[21] CAVERLEY, J.D. Democratic Militarism: Voting, Wealth, and War. Cambridge: Cambridge University Press, 2014, 314 p. ISBN 978-1-107-66737-2.

[22] GARTZKE, E. Democracy and the Preparation for War: Does Regime Type Affect States' Anticipation of Casualties? International Studies Quarterly, 2001, vol. 45, no. 3, p. 467-484.

[23] SCHÖRNIG, N. Liberal Preferences as an Explanation for Technology Choices. The Case of Military Robots as a Solution to the West's Casualty Aversion. In CARPES, M., MAYER, M. and KNOBLICH, R. (eds) The Global Politics of Science and Technology - Vol. 2: Perspectives, Cases and Methods. $2^{\text {nd }}$. Bonn: Springer, 2014, p. 67-82. ISBN 978-3-642-55009-6.

[24] BARKAN, N., BLAND, C. and CULVER, W. Robotics and Autonomous Systems 2011 [on line]. In: Industry Study: Final Report, 2011. 46 p. [cited 2017-08-06]. Available from: <http://es.ndu.edu/Portals/75/Documents/industry-study/reports/2011/icaf-is-report-robotics-autonomous-systems-2011.pdf $>$.

[25] JOHNSON, R.A. and WICHERN, D.W. Applied Multivariate Statistical Analysis. New Jersey: Prentice Hall, 1992, p. 481-538. ISBN 978-0-13-187715-3.

[26] DEPARTMENT OF STATISTICS. Cluster Analysis: Ward's Method [on line]. State College: Eberly College of Science, 2004. [cited 2017-03-04]. Available from: <http://sites.stat.psuedu/ ajw13/stat505/fa06/19_cluster/09_cluster_wards. html $>$.

[27] MOOI, E. and SARSTEDT, M. Cluster Analysis. In: A Concise Guide to Market Research. Berlin: Heidelberg, 2011. p. 250-254. ISBN 978-3-642-12541-6.

[28] NCSS Statistical Software. Hierarchical Clustering/Dendrograms [on line]. Kaysville: NCSS Statistical Software, 2004. [cited 2017-12-12]. Available from: $<$ https://ncss-wpengine.netdna-ssl.com/wp-content/themes/ncss/pdf/Procedures/ NCSS/Hierarchical_Clustering-Dendrograms.pdf $>$. 
[29] FARLEY, R. The Five Most Deadly Drone Powers in the World [on line]. In The National Interest. Washington: National Interest, 2015. [cited 2017-08-06]. Available from: <http://nationalinterest.org/feature/the-five-most-deadly-drone-powers -the-world-12255? page $=2>$. 